\title{
ЗДОРОВЬЕ КАК ЖИЗНЕННАЯ ЦЕННОСТЬ ЧЕЛОВЕКА
}

\author{
В.А. Енохович, В.С. Писчиков, М.М. Холин
}

\author{
Здоровье - вид гармонии, но его пре- \\ делы очень широки и не у всех из нас \\ одинаковы.
}

Гален

Своеобразие человека как живого существа состоит прежде всего в том, что он принадлежит одновременно нескольким мирам - природному и социальному, духовному и материальному. Сочетание и противоречивое взаимодействие их обнаруживается во всех атрибутах, проявлениях и состояниях человеческой природы. С наибольшей полнотой и определенностью - в здоровье человека.

Здоровье всегда воспринималось человеком как одна из важнейших его жизненных ценностей. Но особенно актуализировалась проблема сохранения и укрепления здоровья человека в XX - начале XXI столетий в контексте продолжающегося прогрессирования «болезней цивилизации», приобретающего характер эпидемии и угрожающего существованию человечества СПИДа, все более широко распространяющегося международного терроризма, нарастания количества и масштабов стихийных природных бедствий и рукотворных катастроф. В этих условиях, как никогда прежде, стала очевидной незащищенность и хрупкость человеческой жизни, уязвимость здоровья человека.

Длительное время здоровье человека было преимущественно предметом исследования медицины. В настоящее время ситуация радикально изменилась: кроме медицины, здоровье стало объектом изучения и ряда других наук - валеологии, психологии, экологии, биологии, биоэтики, социологии. В рамках философии сейчас формируется особая дисциплина - философия медицины. Как следствие этого - изменение онтологического и гносеологического статуса категории «здоровье». Если прежде

Актуальні проблеми духовності

(Відп. ред.: Я.В. Шрамко)

Кривий Ріг (2005), 297-305 
она рассматривалась как специфически медицинское понятие, то сейчас доминирует тенденция интерпретировать категорию здоровья как междисциплинарное понятие.

Такой подход, на наш взгляд, методологически является единственно верным, поскольку отражает понимание здоровья как характеристику не только организма индивида, но и его личности. Здоровье при этом предстает как интегральное качество индивида, позволяющее ему успешно осуществлять необходимые и разнообразные функции субъекта жизнедеятельности: «Здоровье - это состояние полного физического, психического и социального благополучия человека»- так определяет здоровье Всемирная организация здравоохранения (1949).

В связи с пониманием здоровья как системного качества индивида, возникает вопрос: как следует относиться к таким широко используемым в современной медицинской, валеологической и иной научной литературе понятиям как «физическое здоровье», «психическое здоровье», «нравственное здоровье», «социальное здоровье» и даже- «медицинское здоровье»?

Если быть последовательным, то использование этих терминов надо признать неправомерным: они вступают в противоречие с пониманием здоровья как целостного качества человека, что в настоящее время фактически общепризнанно в научной литературе и очевидно в жизненной практике, включая медицинскую. Ведь никто же всерьез не станет утверждать, что физически здоровый, но психически больной или неполноценный в социальном отношении индивид - это здоровый человек. Аналогично невозможно назвать здоровым психически и социально нормального, но больного физически (например, СПИДом) индивида. Поэтому в теоретическом отношении корректнее использовать вместо терминов «физическое (психическое, социальное) здоровье» термины «физический (психический, социальный) аспект здоровья». При условии же использования терминов «физическое (психическое, социальное) здоровье» (стилистически лучше звучит!) не следует забывать об их условности.

Дискуссия о содержании категории «здоровье человека» имеет не только теоретическую значимость, но и выход в практическую деятельность. Применение более корректного в гносеологическом смысле понятия здоровья позволяет: а) более успешно разрабатывать и правильно выстраивать схемы сохранения, укрепления и восстановления здоровья, а также лечения болезни; б) эффективнее организовывать систему обучения валеологическим знаниям и приемам; в) объединять вокруг теоретического и практического решения всех вышеназванных проблем усилия специалистов естественнонаучного, гуманитарного и технического направлений, а не только врачей и валеологов. Это, несомненно, открывает возможности комплексного, более глубокого исследования и практическо- 
го разрешения разнообразных проблем здоровья человека.

Признание междисциплинарного характера категории «здоровье», на первый взгляд, вступает в противоречие с тем, что им (здоровьем человека) занимается прежде всего медицина - как в практическом, так и в теоретическом отношениях. Несмотря на возникновение валеологии и все более активную роль в исследовании проблем здоровья психологии, экологии, биоэтики и др. наук, ключевые позиции медицины в этом остаются неизменными. Как же объяснить это противоречие?

Дело в том, что физическая (точнее, физиологическая, биологическая) составная здоровья человека исследуется и практически поддерживается (сохраняется, укрепляется, восстанавливается) прежде всего медициной. Но тело, телесность - это материальная субстанция индивида, на которой «держатся», с которой неразрывно связаны все другие его человеческие качества. Поэтомму невозможно, «перешагивая» через телесное, игнорируя его, эффективно решать психические и социальные проблемы здоровья человека. Даже в тех случаях, когда непосредственной причиной сбоев, неполадок в функционировании тела являются психические аномалии (например, болезни нервной системы). О правильности такого подхода со всей определенностью свидетельствует и понимание медициной природы болезни как «состояния, обусловленного нарушениями структуры и функций организма и его реакциями на эти нарушения... В основе этого состояния всегда лежат те или иные нарушения гомеостазиса» [3, с. 187]. Весьма модный сейчас призыв искать исток едва ли не всех болезней тела в состоянии души (духа) и врачевать их, а не тело,- - на практике оказывается не более, чем бессодержательным, хотя и привлекательным, красивым лозунгом.

Признание лидирующей роли медицины среди наук о здоровье человека имеет немаловажное прикладное следствие: непосредственно, практически заниматься проблемами здоровья человека, а так же готовить необходимые для этого кадры эффективно могут лишь профессионалы, то есть лица, получившие специальное медицинское образование. Только при соблюдении этого необходимого условия возможно реальное осуществление валеологических принципов сохранения, укрепления и восстановления здоровья. В противном же случае валеологии угрожает поверхностный дилетантизм, падкий на все модное и экстравагантное, следствием чего может быть не польза, а вред здоровью тех, кто стал жертвой этого «всезнающего», «всемогущего» дилетантизма.

Здоровье человека как одна из важнейших его жизненных ценностей всегда, во все времена было актуальной и весьма непростой проблемой для него. Однако сложность и острота этой проблемы для современного человека, как уже упоминалось нами, беспрецедентны в истории общества. Сберечь себя как вид Homo sapiens или постепенно превратиться 
в деградирующее существо и в конце концов исчезнуть с лика планеты, - такова дилемма, которую должно разрешить человечество в XXI столетии. В ее решении недостаточно усилий лишь на уровне всеобщего и общего - человечества, региональных объединений и союзов государств, отдельного социума. Недостаточно, какими бы правильными и решительными ни были принимаемые ими меры. Эта глобальная проблема с необходимостью должна трансформироваться в индивидуальную, стать проблемой каждого человеческого индивида. В данном ракурсе она содержательно развертывается в плоскости соотношения категорий «объективное»- «субъективное»: что может каждый индивид в ее решении, а что от него не зависит, несмотря на его добрую волю и усилия и, следовательно, должно взять на себя общество?

Объективными детерминантами здоровья человека являются его наследственность и влияние внешней среды в ходе онтогенеза, в процессе их взаимодействия формируется характерная для индивида конституция как совокупность относительно устойчивых морфологических свойств его организма. Хотя индивид и не волен выбирать конституцию, он может вносить в нее определенную коррекцию в направлении сохранения, укрепления и совершенствования своего здоровья или, напротив, ухудшения и разрушения его. С момента выбора индивидом своей профессии к числу объективных факторов его здоровья добавляется и такой важный, как трудовая деятельность, которую он осуществляет.

Внешняя среда как объективная детерминанта здоровья человека весьма разнообразна по своему содержанию и структуре, динамична в своей изменчивости. Мы хотели бы обратить внимание на две исключительно важные для здоровья человека ее особенности, явно обозначившиеся в прошлом и все более прогрессирующие в нынешнем столетии. Первая из упомянутых особенностей - это качественное изменение экосистемы человека, приобретающее все более радикальный характер. Речь идет о том, что экосистема, в которой сформировался человек как вид, чем дальше, тем больше в своей первозданности уходит в прошлое. Она стремительно превращается из естественной в искусственную: «Экосистема современного человека, базируясь на основе природной среды, по сути полностью создана его руками и разумом, ее целостность поддерживается человеческой деятельностью, зависит от нее» [1, с.68].

Это создает для здоровья человека разнообразные проблемы, связанные с необходимостью адаптации к неблагоприятным изменениям среды его обитания. Количество и качество этих изменений столь значительны, что человеку все труднее к ним приспосабливаться. В результате «формируется стойкая тенденция к постоянному ухудшению механизмов адаптации современного человека» и «процесс утраты биологических и создание искусственных адаптационных механизмов человеческого организма 
постоянно ускоряется» $[1$, с. 68,70$]$. Проявлением данной тенденции стали все более широкое распространение в мире «болезней цивилизации», генетически обусловленных заболеваний, врожденной патологии др. аномалий в здоровье человека.

Другая особенность внешней среды обитания современного человека это изменения в культурной основе его жизнедеятельности, наметившиеся в связи с процессом глобализации. Разновекторные последствия, которые вызывает в жизни человечества глобацизация, в культуре все отчетливее приобретают форму унификации ценностей - цивилизационных, региональных, национальных. Безусловно, это очень важная и далеко не однозначная тенденция в развитии культуры, которая по-разному оценивается философами, культурологами, социологами. На первый взгляд, эта тенденция не имеет никакого отношения к здоровью человека, и если иметь в виду непосредственную связь между ними, то это действительно так. Однако опосредованно такая связь есть и осуществляется она через экосистему человека.

Изменения в экологии культуры, в данном случае тенденция к унификации, существенно преобразуют экосистему человека в целом и тем самым определенным образом влияют на его здоровье. Какова же направленность этого воздействия? Очень многие исследователи данной проблемы приходят к обоснованному, на наш взгляд, выводу о негативном характере такого воздействия. Унификация жизненных ценностей в масштабе всего человечества подрывает объективные, исторически сложившиеся основы образа жизни людей, характерные для разных культур (например, для западной и восточной), континентов, народов и наций. Этот процесс дестабилизирует экосистему человека, порождая разнообразные, часто непредвиденные проблемы для его здоровья. В то время, как «культурно-этнографическое разнообразие народов, населяющих землю, как и видовое разнообразие в биологических системах, имеет огромное значение для устойчивости экосистемы человека» [1, с. 71].

Качественная трансформация среды обитания человека как следствие развития современной техногенной цивилизации актуализирует роль образа жизни в сохранении, укреплении и восстановлении его здоровья. Образ жизни человека на индивидуальном уровне его бытия, то есть как способ существования отдельного индивида, детерминирован двояко: объективными условиями его жизнедеятельности и самим индивидом,- субъективно. В контексте существенных объективных изменений в экосистеме человека на первый план выступает способность и готовность каждого индивида адекватно реагировать на эти изменения, то есть возрастает значимость субъективного начала в коррекции своего образа жизни. Таким началом является внутренний мир индивида - его воля и способности, потребности и интересы, знания, нравственные ценности и 
в целом мировоззрение.

Жизнь дает немало примеров тому, как богатство и развитость духовного мира индивида коррелируют с высоким уровнем развития его естественных сил и эффективной самореализацией. Однако можно найти не меньше примеров противоположного свойства, когда нормально развитый телесно и психически, включенный в социальную деятельность индивид, то есть вполне здоровый во всех смыслах, обладает весьма низким (если не сказать сильнее) уровнем духовного развития. Наконец, встречаются случаи (их тоже немало), когда очень серьезная, хроническая болезнь тела не становится непреодолимой преградой на пути духовного развития и постоянного самосовершенствования личности: ярчайший и общеизвестный пример тому-выдающаяся украинская поэтесса Л. Украинка, ее жизнь и судьба.

Возникает вполне логичный вопрос: является ли сказанное выше достаточным основанием для вывода об индифферентности друг к другу тела и духа, то есть о существовании своего рода «параллелизма» в их взаимосвязи? Если да, то как же быть с гиппократовским «в здоровом теле - здоровый дух!» и галеновским «здоровье- вид гармонии»? Устами великих в данном случае глаголет абсолютная истина: здоровье как системное, интегральное состояние индивида - это всегда гармония. Но ведь гармония - это не абсолютное согласие, созвучие (1) и осуществляется она на определенном уровне развития компонентов системы (2). Если иметь ввиду здоровье как систему, то это не максимальный, а минимальный уровень развития всех его составных, теоретически и в согласии с жизненной практикой определяемый медициной как норма.

Такой показатель необходим только для того, чтобы разграничить противоположные качественные состояния индивида - нормальное (здоровье) и ненормальное (болезнь) и не больше. Хотя понятие нормы здесь, как, впрочем, и во всем, в определенной степени условно, оно отнюдь не лишено смысла и эмпирически фиксируемо. За границами же нормы - и в здоровье, и в болезни - существует широкий спектр разнообразных различий (половых, возрастных, индивидуальных и др.), на что и обратил внимание Гален, мудро добавив, что пределы здоровья очень широки и не у всех одинаковы.

В контексте отмеченного выше становится понятным, почему в возовском определении здоровья отсутствует понятие «духовное», но присутствует «психическое». Безусловно, эти понятия родственны, но отнюдь не тождественны. Не предпринимая гносеологического анализа их соотношения (в этом, исходя из наших целей, нет необходимости), отметим следующее. В субстанциальном отношении психическое не материально, а идеально и в этом смысле (и только в этом!) духовно. Но понятие «духовное» имеет и другие смыслы, которых нет в понятии «психическое». Это 
различие становится понятным, если сравнить человека и высших животных. K «внутреннему миру» последних в науке безо всяких оговорок применяется термин «психика», но вполне обоснованно никто не говорит об их духовном мире или духовности. В определении здоровья термин «психическое» предназначен для обозначения того минимального уровня духовного развития индивида, который необходим для его нормальной жизнедеятельности.

Если психическое состояние непосредственно и с необходимостью характеризует здоровье индивида, то об уровне его духовного развития этого нельзя сказать. Тем более это так, если речь идет о духовности, понимаемой не как синоним духовного мира, а как определенное его качество, обусловленное ориентацией на высшие нематериальные ценности человеческого бытия - добро, любовь, истину, красоту, справедливость, свободу и др. Понятие духовности характеризует высокий уровень развития внутреннего мира, которым не каждый здоровый индивид обладает. Из этого, конечно, не следует, что духовность никак не влияет на здоровье индивида. Связь между ними, несомненно, существует: «Как известно, без энергетического насыщения не может существовать ни одно живое тело, ни один живой организм. Но исключительную роль здесь играет «духовная энергия» человека: его и как организма, и как личности» $[4$, c. 77]. Однако все же наибольшее воздействие духовности на здоровье индивида осуществляется непосредственно через его образ жизни.

Как совокупность духовных чувств и интересов индивида, его убеждений и идеалов, имеющих нравственно-гуманистическую интенцию, духовность непосредственно обусловливает его жизненные ориентации, стандарты и нормы поведения, а тем самым, в значительной степени, и его образ жизни. Воздействие же образа жизни индивида на его здоровье очевидно и столь велико, что зачастую является решающим. Характер этой связи со всей определенностью выражен в понятиях «здоровый образ жизни» и «нездоровый образ жизни».

Здоровый образ жизни не только укрепляет и сохраняет здоровье индивида, способствуя его плодотворному долголетию, но и может улучшать, совершенствовать здоровье. Причем это относится ко всем его ингредиентам - как биологическому, что наиболее очевидно, так и психическому, и социальному. Однако индивид может жить и так, что его образ жизни подрывает, разрушает здоровье, ухудшая качество и сокращая время его жизни. Нередко такой образ жизни является следствием бездуховности индивида, которая ведет к «снижению жажды жизни, а это, в свою очередь, - к бездуховности» [2, с.156]. Нарушение ритма обменных процессов, нервное перенапряжение и стрессы, дестабилизация гомеостаза, снижение иммунитета, наконец, возникновение болезни. Таковы последствия для индивида его нездорового образа жизни. 
Рассматривая характер влияния на здоровье индивида его образа жизни важно учитывать и такой атрибут каждого человека, как его своеобразие, индивидуальность. Поскольку каждый индивид обладает неповторимыми генетическими и прижизненно сформированными особенностями организма, своеобразием психики и личности, то понятие здорового образа жизни методологически неверно рассматривать как всеобщий стандарт, алгоритм поведения. Определенные принципы и правила, требования и рекомендации, составляющие содержание здорового образа жизни, следует рассматривать как общие ориентиры, образцы, предполагающие их соотнесение со своей индивидуальностью, преломление через ее призму. Ведь то, что полезно для здоровья одному, может вполне оказаться безразличным другому и даже вредным третьему.

Особую значимость в процессе воздействия духовности на здоровый образ жизни индивида имеют его моральные качества. Составляя ядро духовности, моральные ценности выступают в качестве основы выработки индивидом своих повседневных жизненных ориентаций и установок, руководствуясь которыми он принимает одно и отвергает другое. Жизненная практика свидетельствует, что аморальность души и образа жизни не совместимы со здоровым психическим самочувствием индивида, являются причиной хаотичности, неразборчивости в его действиях и поступках. Все это дестабилизирует организм и личность, подрывает и разрушает здоровье индивида. Типичный и убедительнейший пример этому - алкоголизм и наркомания, а весьма часто и СПИД.

Осознание исключительно важной роли образа жизни индивида для его здоровья позволяет более адекватно посмотреть на проблему формирования здорового образа жизни. Очевидно, что решение этой проблемы выходит далеко за пределы возможностей медицины и валеологии в сохранении и укреплении здоровья человека. Она предстает как сложная, многоаспектная проблема, имеющая широкий социальный контекст. Пути и формы ее решения в значительной степени связаны с национальными, профессиональными, возрастными, половыми, индивидуально-личностными и др. особенностями человека.

В преломлении к такой социальной группе как молодежь, в частности, студенческая молодежь, проблема формирования здорового образа жизни, согласно этому подходу, не может рассматриваться как проблема исключительно двух кафедр вуза - физического воспитания и валеологии. В той или иной мере она касается деятельности всех кафедр: биолог и химик, физик и географ, педагог и психолог, социолог и философ, представители всех дисциплин могут вносить свой незаменимый вклад в формирование здорового образа жизни студента. Все они, кроме кафедры физического воспитания, апеллируют при этом к сознанию студента, стремясь воздействовать на его духовный мир. Философ это делает, 
подводя теоретическое основание под развивающееся мировоззрение студента, способствуя выработке у него диалектического стиля мышления, что открывает ему возможность мыслить шире и глубже, адекватнее воспринимать себя и жизнь, различать в ней истинные и мнимые ценности.

\section{1 Литература}

[1] Алексеев C.В., Янушанец О.И. Бег по кругу. Системный взгляд на здоровье человека // Экология и жизнь. $-2003 .-$ №6.

[2] Коломієць О. Філософсько-гуманістичні проблеми медичної біоетики // Філософська думка. - 2003. - №2.

[3] Саркисов Д.С., Пальцев М.А., Хитров Н.К. Общая патология человека.-М., 1997.

[4] Хрусталев Ю.М. Философско-этический характер медицины // Философские науки. -2004. - №8. 